\title{
ANAXIMANDER'S SPARTAN SUNDIAL
}

As the author of the earliest secular account of the universe's formation, Anaximander of Miletus can lay a strong claim to the title of first Greek cosmologist. ${ }^{1}$ Tradition also credited him with invention of the first time-telling instruments: 'He was the first to construct gnomons for the identification of solstices, time spans, horai and the equinox'

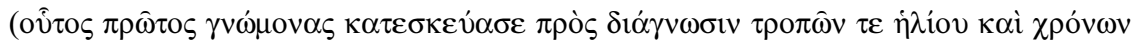

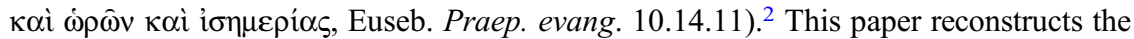
location, design and function of a $\gamma v \omega \mu \omega v$ which he erected at Sparta, and moots some intriguing parallels with the Augustan Horologium on the Campus Martius. Before we turn to the evidence, however, two points of terminology need to be clarified. The Greek term $\gamma \nu \omega \mu \omega \nu$ can denote either a sundial—a pointer attached to a surface with marks for tracking its shadow-or the pointer itself, in English also called the gnomon; Eusebius' reference to the identification of times suggests that what Anaximander created was in fact a sundial. ${ }^{3}$ Now, depending on its design, a sundial can tell either the hour of the day, the season of the year, or both; from Eusebius' text it is not clear which function Anaximander's dial possessed, since the noun $\hat{\hat{\rho}} \rho \alpha \mathrm{l}$ can mean either 'hours' or 'seasons'. But only one usage of the word would be appropriate for the sixth century: no authors refer to hours of the day prior to Herodotus (2.109) and there is no evidence for Greek sundials displaying hours prior to $c .350$ B.c.; by contrast, the use of $\omega \rho \alpha$ to mean 'season of the year' is as old as Homer and Hesiod, and the solstices and equinoxes mentioned by Eusebius demarcate the transitions between the seasons. ${ }^{4}$ Anaximander's device was a sundial, then, one which tracked seasons rather than hours. According to Diogenes Laertius, the cosmologist set up one such device at Sparta (2.1):

\footnotetext{
${ }^{1}$ Although Thales may have preceded Anaximander as the exponent of a secular cosmology, the latter wrote a book on the subject, while Thales' views seemingly took the form of aphorisms. For Anaximander's doctrines, see C.H. Kahn, Anaximander and the Origins of Greek Cosmology (New York, 1960) and the new collection of fragments in G. Wöhrle, Die Milesier: Anaximander und Anaximenes (Berlin, 2012). D. Couprie, Heaven and Earth in Ancient Greek Cosmology. From Thales to Heraclides Ponticus (New York, 2011), 89-162 offers a good overview of his cosmology and astronomy. I would like to thank the journal's referee for helpful comments and criticisms.

${ }^{2}$ Cf. Suda s.v. 'Av $\alpha \dot{\xi} \mu \alpha v \delta \rho o \varsigma$ (A 1986).

3 On ancient sundials in general, see S.L. Gibbs, Greek and Roman Sundials (New Haven, 1976); R. Hannah, 'Time-telling devices', in G. Irby (ed.), A Companion to Science, Technology, and Medicine in Ancient Greece and Rome (Hoboken, NJ, 2016), 923-40.

${ }^{4}$ For early references to the seasons, see Hom. Il. 6.148, Od. 5.485, Hes. Op. 450, 584, etc. The first reference in Greek literature to a specific hour of the day occurs in Hippoc. Epid. 4.12, a text dated to around 400 B.c. (cf. J. Jouanna, M.B. DeBevoise [trans.], Hippocrates [Baltimore, 1999], 389). For the oldest preserved remains of a sundial, see K. Schaldach, 'The arachne of the Amphiareion and the origin of gnomonics in Greece', JHA 35 (2004), 435-45.
} 


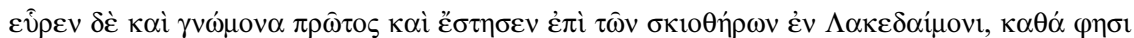

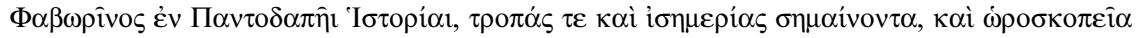

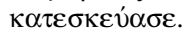

He was also the first to invent the sundial and installed one on 'the shadow-hunters' at Sparta which indicated solstices and equinoxes, as Favorinus says in his Miscellaneous History, and constructed horoskopeia.

Pliny the Elder seems to refer to the same device in a report which contains a mistaken substitution of Anaximenes for Anaximander (HN 2.187): ${ }^{5}$

umbrarum hanc rationem et quam uocant gnomonicen inuenit Anaximenes Milesius, Anaximandri de quo diximus discipulus, primusque horologium, quod appellant sciothericon, Lacedaemone ostendit.

Anaximenes of Miletus, a student of the Anaximander about whom we have spoken, discovered the theory of shadows and what people call gnomonics, and first made public a sundial, which they call the 'shadow-hunter,' at Sparta.

Where in Sparta did Anaximander install his sundial? Diogenes specifies that it was

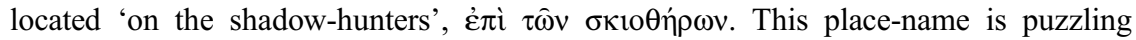
because $\sigma \kappa i o ́ \theta \eta \rho o v$ is another Greek synonym for 'sundial' (LSJ s.v.); Anaximander could hardly be called the inventor of the sundial if the site where his instrument was installed had already been named for the device. Hence the suggestion made by some scholars that the site acquired its name, $\tau \dot{\alpha} \sigma \kappa i o ́ \theta \eta \rho \alpha$, through its association with Anaximander's instrument: 'perhaps there was a prominence in Sparta later known as "the sundials", from the gnomon or gnomons that existed there.' ${ }^{6}$ But where in Sparta were public sundials to be found? No collection is mentioned in our sources, nor did any location bear that name. Yet, one name comes close: in his description of the area around the Spartan marketplace Pausanias refers to an object he calls the $\Sigma \kappa i \alpha ́ s(3.12 .10)$ :

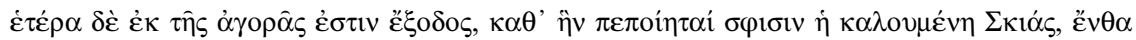

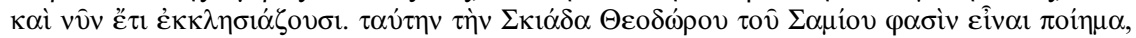

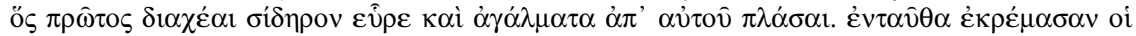

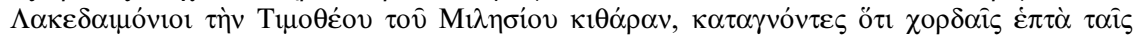

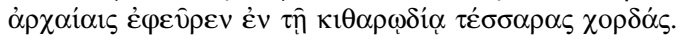

There is another exit-road from the marketplace, down which the so-called Skias was made for them at a place where even at the present day they hold their meetings of the Assembly. This Skias, they say, was the work of Theodorus of Samos, who was the first to discover how to melt iron and cast statues made from it. This is where the Lacedaemonians hung the harp of Timotheus of Miletus to condemn his innovation in harp-playing of adding four strings to the seven old ones.

Here then we have a public structure in Sparta with the root $\sigma \kappa 1 \alpha-$ in its name. Munn has noted the match in nomenclature and proposed that the $\Sigma$ kiós was the site of Anaximander's gnomon. ${ }^{7}$ The match is a significant one, I believe, but like most commentators Munn assumes that the object was a building, an assumption that

\footnotetext{
${ }^{5}$ For the correction, see E. Mensching, Favorinos von Arelate (Berlin, 1963), 114; Anaximenes and Anaximander are likewise confused by John Lydus, De Mensibus 3.12, p. 53 Wuensch.

${ }^{6}$ G.S. Kirk, J.E. Raven and M. Schofield, The Presocratic Philosophers (Cambridge, 1983), 103; likewise, Mensching (n. 5) and C.J. Classen, 'Anaximandros', RE Suppl. 12 (1970), 33.

7 M. Munn, The Mother of the Gods, Athens, and the Tyranny of Asia (Berkeley, 2006), 200-3.
} 
conflicts with other evidence. ${ }^{8}$ A building would have to be quite large in order to accommodate the entire Spartan assembly, yet while archaeologists have identified its general location, no traces of such a massive edifice have been found. ${ }^{9}$ Moreover, according to Plutarch, Lycurgus expressly forbad the Spartans from constructing such a structure; Plutarch also implies that the assembly met on open ground (Lyc. 6.1-3). The noun Pausanias uses to describe the $\Sigma \kappa i \alpha \varsigma, \pi o i n \mu \alpha$, is reserved elsewhere in his text for items such as statues or furniture. ${ }^{10}$ Thus, the $\Sigma \kappa i \alpha$ s was likely not a building at all but a monument defining the open space where the assembly met. The material from which it was made can also be inferred. Pausanias specifically identifies its maker Theodorus as the inventor of iron casting, and adds elsewhere that, although Theodorus pioneered bronze casting, he nowhere saw any of Theodorus' works in bronze (10.38.6). Together these passages imply that the $\Sigma \kappa i \alpha ́ \varsigma$ Pausanias saw at Sparta was made of iron, a material which at the time was used for constructing

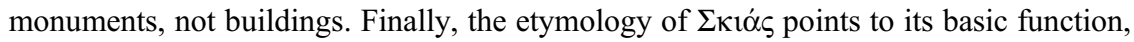

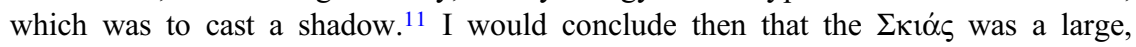
statuesque object composed of iron, the shadow of which fell on the ground where the Spartan assembly met; given the repertoire of shapes available in the mid sixth century, a free-standing pillar would seem to be the most likely form. ${ }^{12}$

The similarity between such a monument and a sundial can hardly be coincidental. By combining the information in Diogenes and in Pausanias we can venture a guess at how the 'sundial on the shadow-trackers' and the $\Sigma \kappa i \alpha$ ' $\varsigma$ on the edge of the agora were related. One possibility is that the column, the $\Sigma \kappa i \alpha ́$, was topped by a smaller object, a gnomon, which served to define the end of the shadow; the monumental sundial Augustus had erected on the Campus Martius was similarly articulated into two parts, a stone obelisk with a golden sphere on the top (Plin. $H N$ 36.72, quoted below). Another possibility is that the pillar was an unarticulated structure, which functioned

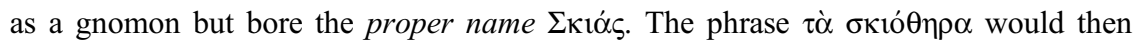
denote the surrounding area 'on which' ( $\dot{\varepsilon} \boldsymbol{i}+$ gen.) the pillar was erected, its name deriving from the monument. It is hard to tell whether Diogenes' $\sigma \kappa i o ́ \theta \eta \rho \alpha$ or Pliny's skiothericon is a more accurate record of the name of the place, and in the absence of fuller evidence it would be unwise to press the details much further. Still,

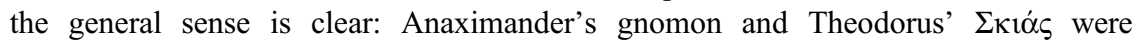
either the same monumental object or formed part of the same object, a sundial situated on the meeting grounds for the Spartan assembly.

\footnotetext{
${ }^{8}$ See e.g. H. Mitchell, Sparta (Cambridge, 1964), 146; for a fuller discussion of the evidence, see I. Shatzman, 'The meeting place of the Spartan assembly', RFIC 96 (1968), 385-9.

9 The site can be identified by its proximity to a 'round building', supposedly the work of the seer Epimenides, whose remains have been identified: see C. Waldstein and C.L. Meader, 'Reports on excavations at Sparta in 1893', AJA 8 (1893), 410-28. The identification has recently been supported by G.D.R. Sanders, 'Platanistas, the Course and Carneus: their places in the topography of Sparta', British School at Athens Studies 16 (2009), 195-203, at 201.

${ }^{10}$ Statues: $1.23 .8,2.10 .1,2.19 .3,4.32 .1,5.11 .8,5.24 .1,8.22 .7,8.42 .5$, etc.; furniture: 1.27.1, 9.41.2.

${ }^{11}$ Elsewhere the noun denotes a tent or canopy (LSJ s.v.); but note Pausanias' addition of the

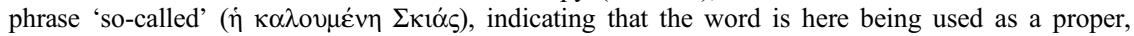
not as a common, noun.

${ }^{12}$ Compare the free-standing column set up around the same time (c.550 B.c.) at Delphi, which supported the so-called Naxian Sphinx; and the bronze 'Serpent Column', also at Delphi, erected as a memorial to the Greek victory at Plataea in 479 B.C. Further, D. Donos, Studien zu Säulen- und Pfeilermonumenten der archaischen Zeit (Hamburg, 2008).
} 
While the collaboration between Anaximander and Theodorus presupposed by this reconstruction is not explicitly attested, the connection is quite plausible. The philosopher and the architect/inventor came from neighbouring Ionian cities and were contemporaries (both active $c .570-530$ B.c.). As Hahn has demonstrated, Anaximander's cosmology was influenced by technologies being developed at this time by Theodorus and other architects. ${ }^{13} \mathrm{~A}$ few examples of their overlapping interests may be cited: Anaximander likened the earth to a stone pillar with proportions matching those of a column drum (Hippol. Haer. 1.6.3), while Theodorus devised techniques for the precision crafting of large column drums (Plin. $H N$ 36.90). Anaximander compared the sun to the vent-hole in a blast furnace (Aët. 2.20.1), while Theodorus made crucial advances in metal-casting technology, alluded to above. And while Anaximander turned the gnomon into a time-telling instrument, Theodorus pioneered the use of the gnomon as a building tool (the norma of Plin. $H N$ 7.198). Finally, Theodorus is said to have worked with collaborators, sharing design-duties with Rhoecus of Samos on the Heraion and offering advice to Chersiphron and Metagenes of Crete on the foundation structure for the Artemision at Ephesus. ${ }^{14}$ Sparse as our sources for this period are, they nevertheless make credible the notion that Anaximander helped to design a sundial which Theodorus cast in metal.

It may seem strange to find such a piece of cutting-edge astronomical technology in archaic Sparta of all places, yet some further pieces of evidence make this association less surprising. Let us start by recalling that Anaximander's gnomon marked the times of transition from one season to the next. According to Plutarch, the Spartan Rhetra-the oracle from Delphi which prescribed Sparta's constitutional forms-said that the Spartan people were to assemble $̋ \rho \alpha \varsigma \dot{\varepsilon} \xi \omega \rho \alpha \varsigma$ (Lyc. 6.2). As Wade-Gery notes in a discussion of this passage, the correct literal translation of this phrase, with its singular nouns, is 'from season to season', or 'season after season'-though he, along with other scholars, maintains that the phrase actually means 'once a year' or perhaps 'once a month'. ${ }^{15}$ There is no warrant for modifying the sense, however. The interpretation 'once a year' is based on parallel passages where $̋ \rho \alpha$ appears in the

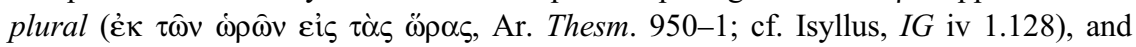
the rendering 'once a month' is based on a scholium to Thucydides (ad 1.67.3) which says only that the Spartan assembly met at full moon. Neither of these texts provides sufficient basis for rejecting the plain implication of the phrase $̋ \rho \alpha \varsigma \dot{\varepsilon} \xi$

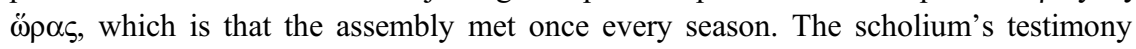
can be reconciled with the text of Plutarch by assuming that the meeting fell on the first full moon after the season began; a similar lunar-solar rule governed the timing of the Olympics, the first day of which coincided with the eighth new moon after winter solstice. ${ }^{16}$ At Sparta, then, the seasons assumed a special importance as measures of time thanks to the injunction of the Rhetra. ${ }^{17}$ Having a sundial to mark their occurrence

13 R. Hahn, Anaximander and the Architects (Albany, NY, 2001); id. Archaeology and the Origins of Philosophy (Albany, NY, 2010).

14 R.R. Holloway, 'Architect and engineer in archaic Greece', HSPh 73 (1969), 281-90.

15 H.T. Wade-Gery, 'The Spartan Rhetra in Plutarch, Lycurgus VI: A. Plutarch's text', CQ 37 (1943), 62-72; similarly, N.G.L. Hammond, 'The Lycurgean reform at Sparta', JHS 70 (1950), $42-64$, at 43.

16 The rule is stated by a scholium on Pind. Ol. 3.33, although the interpretation of this text is controversial; see further A.E. Samuel, Greek and Roman Chronology. Calendars and Years in Classical Antiquity (Munich, 1972), 191-4.

${ }^{17}$ It may be no coincidence that the earliest mention in Greek of all four seasons together appears in 
would have made it easier for the Spartans to decide when the assembly should meet. Its location on the assembly's meeting grounds would have allowed it to serve the needs of that body.

Another feature of the Spartan sundial merits consideration. In addition to a gnomon and a space where it can cast its shadow, a functioning sundial needs markers on the space to indicate times. An hourly sundial requires twelve points to be marked, but a dial indicating the seasons needs just three: one near the gnomon's base which the shadow's tip will touch at summer solstice, another further out to mark the spring and autumn equinoxes, and a third even further away for the winter solstice. If the marks are placed on a line drawn northward from the base, the shadow's tip will touch them on the appropriate day at local noon; because of its connection to midday, this kind of simple structure is often referred to as a meridian line. ${ }^{18}$ Now, Diogenes Laertius concludes his sentence about Anaximander's sundial by noting that he also constructed $\dot{\rho} о \sigma \kappa к \pi \varepsilon i \hat{\alpha}$. The noun, which is very rare, elsewhere has the meaning 'sundial' (LSJ s.v.). If Diogenes' claim is interpreted 'Anaximander discovered the sundial and erected one at Sparta and constructed sundials', the last phrase is clearly otiose. An alternative construal thus seems preferable: take the noun $̋ \rho \alpha$ to mean

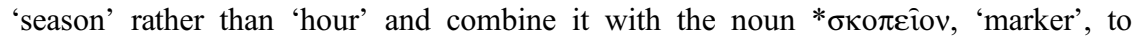
yield the meaning 'season-marker'. This would be an appropriate name for the seasonal markers a meridian line would require. While it is not essential to my argument, I would venture the suggestion that the $\dot{\rho} о \sigma \kappa о \varepsilon \varepsilon \hat{\alpha} \alpha$ were markings or stones laid out on the meeting ground at Sparta by Anaximander to show when each of the four seasons would begin.

The proportions of this object can also be plausibly estimated, even if its exact height is unknown. The meridian line would have to be long enough to measure the shadow at its maximum noon length, which it would reach on the winter solstice, the sun then standing at an elevation of just over 29 degrees above the horizon. At that moment the shadow would be $\sim 1.8$ times longer than the gnomon's height; hence, if the pointer were 2 metres tall, the meridian line would have to be 3.6 metres long, if 4 metres tall, 7.2 metres long, and if 6 metres tall, 10.8 metres long. The open ground where the dial was located must have been more than 10 metres across even at its minimum extent if it was capable of holding the entire Spartan assembly, hence a meridian line could comfortably fit within the space, even if connected to a gnomon several metres tall. The meeting grounds, so Pausanias tells us (3.12.11), lay adjacent to a round temple built by the seer Epimenides, which was quite large, 43 metres in diameter according to its excavators. ${ }^{19}$ A pillar on a broad open space adjacent to a large temple would not appear out of scale with its surroundings even if it was quite tall.

Are there parallels in the ancient world for such a large public sundial? One possible analogue was noted above in the great sundial which Augustus had constructed on the Campus Martius, the so-called Horologium Augusti. The gnomon for Augustus' structure was an obelisk nearly 22 metres tall originally constructed by the pharaoh

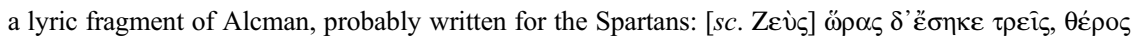

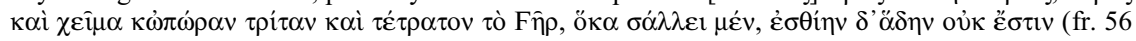
Davies).

${ }^{18}$ The solstice points can be determined by marking where the shadow falls at noon on the days of its greatest and shortest length. There are several ways to determine the equinox points; perhaps the simplest is to count how many days pass from solstice to solstice, identify the day which falls in the middle of this count, then mark the point on the line where the shadow falls on this day.

${ }^{19}$ Waldstein and Meader (n. 9), 410. 
Psammetichus II; the emperor had this removed from its original location in Heliopolis and transported to Rome. ${ }^{20}$ Once in place it threw its shadow across an open area on the Campus bordered to the north by the Mausoleum of Augustus and to the north-east by the Ara Pacis. What sorts of times this sundial indicated has been the subject of a contentious debate. According to Buchner, it marked the hours of the day and the seasons of a year, and indicated Augustus' birthday by throwing its shadow on the front of the Ara Pacis; but evidence for hour-markers is lacking, and the natal alignment, which is very difficult to prove, has not been widely accepted. ${ }^{21}$ There is no doubt however that the Horologium indicated the seasons of the year using a meridian line. A portion of this line has been uncovered by excavation, and Pliny mentions it in his account of the monument, describing it as a stone pavement with bronze markers showing the length of day at different times of the year ( $H N$ 36.72):

ei, qui est in campo, diuus Augustus addidit mirabilem usum ad deprendendas solis umbras dierumque ac noctium ita magnitudines, strato lapide ad longitudinem obelisci, cui par fieret umbra brumae confectae die sexta hora, paulatimque per regulas, quae sunt ex aere inclusae, singulis diebus decresceret ac rursus augeresceret, digna cognitu res, ingenio Facundi Noui mathematici. is apici auratam pilam addidit, cuius uertice umbra colligeretur in se ipsam, alias enormiter iaculante apice, ratione, ut ferunt, a capite hominis intellecta.

To the [obelisk] on the Campus Martius the Divine Augustus added a wonderful feature which allows one to determine the length of the sun's shadow and thus the length of day and night. A stone pavement was made proportional to the length of the obelisk; the shadow matches this pavement [in length] on the sixth hour of the day at winter's end, then gradually shrinks day by day relative to bronze markers laid in the stone, then grows again; the brilliant work of the astronomer Facundus Novius, it is something worth getting acquainted with. To its top he added a gilded sphere whose peak was designed to concentrate the shadow-otherwise the tip would throw it [sc. the shadow] too far; they say Novius understood it to be analogous to a human head.

The parallels between this dial and Anaximander's are striking. Once again we are dealing with a monumental pillar, perhaps featuring an articulated top, which cast its shadow on a meridian line with markers on it; Pliny's regulas would correspond to Anaximander's $\dot{\rho} о \sigma к о л \varepsilon i \alpha$. Like the Spartan gnomon, the obelisk was situated near the heart of the city in a large public space where popular assemblies were traditionally held. And just as the space in the Campus Martius was defined at one end by a round structure, the Mausoleum of Augustus, so the Spartan meeting grounds were bordered by a round building, the temple constructed by Epimenides. Augustus visited Sparta in 21 B.C. (Dio Cass. 54.7.1) and dedicated the obelisk in 10 B.c. Although no doubt much larger in scale and more elaborate in its refinements, his vast time-telling device may well have been inspired by the archaic Spartan monument.

Brooklyn College

PHILIP THIBODEAU pthibodeau@brooklyn.cuny.edu

${ }^{20}$ It is an interesting coincidence, though perhaps no more than that, that Psammetichus' reign, 595-589 B.C., fell within the first half of Anaximander's lifetime, c.610-540 B.C.

21 The literature on this subject is extensive: see E. Buchner, Die Sonnenuhr des Augustus (Mainz am Rhein, 1982); P. Heslin, 'Augustus, Domitian and the so-called Horologium Augusti', JRS 97 (2007), 1-20; M. Schütz, 'The Horologium on the Campus Martius reconsidered', JRA 24 (2011), 78-86; L. Haselberger, The Horologium of Augustus. Debate and Context (Journal of Roman Archaeology Suppl. 99) (Portsmouth, Rhode Island, 2014). 